\title{
TWO GENERATIONS OF BACKPACKERS. IDENTIFYING THE MULTISECTIONAL STRUCTURES OF BACKPACKING TOURISM PARTICIPANTS IN POLAND
}

\author{
JOLANTA BARBARA JABŁONKOWSKA \\ University School of Physical Education in Wrocław, POLAND \\ e-mail: jolanta.jablonkowska@awf.wroc.pl
}

KEYWORDS | alternative tourism, backpacking, the elderly, travelling, Poland

ABSTRACT Backpacking is still an unrecognised issue in Poland. A survey research performed in years 20132014 was to identify the demographic profile of the Polish backpackers. The representative group was chosen with the purposive sampling method. The identity and demographic criteria were assumed basic for the selection. The respondents were 100 representatives aged $18-25$ years and 100 people aged $60-75$. A survey questionnaire was applied to identify and describe the multilayer structures of the backpacking movement in Poland. The paper presents results reflecting the sociodemographic aspects of the Polish backpacker tourism among the young and elderly generations.

\section{Introduction}

Backpacking constitutes an element of the model of alternative and unconventional tourism, and, therefore, of the niche tourism. The backpacking movement in the world emerged in the early 1980s. However, if one assumes drifting to be the prototype for backpacking (Cohen, 2003), it can be stated that the latter already has its own universal traditions: both historical and psychosocial 
(Aitchison, 2003; Jarvis, Peel, 2005; Pearce, 2006; Fischer, Rostami, Peet, Dean, Debattista, Allen, 2010; Tomazos, 2015).

The idea of backpacking is also present in the Polish travelling experience, although it appeared relatively late in Poland. Until 1989, because of the political situation, hindering free border crossing, any individual travelling initiatives were restricted. The socialist authorities introduced passport and foreign currency limitations, which efficiently made passing the borders of the Polish People's Republic impossible. The territory of tourist activity was narrowed down to the countries being part of the Council for Mutual Economic Assistance, e.g. to the areas of the Soviet Union, Bulgaria, Czechoslovakia, Romania, Hungary, the German Democratic Republic (Gaj, 2006). When the marshal law was introduced in Poland in 1981, all instances of tourist movement were absolutely blocked. The borders were closed, and any tourist travelling forbidden. Also, the activity of travelling agencies was suspended. The political freedom to undertake tourist journeys emerged as late as in 1989, whereas the economic one - by the end of the 1990s. Poland slowly began to be open for information on various types of travelling that had already been developing in industrialised countries for a long time. At the beginning of the $21^{\text {st }}$ century, backpacking emerged in Poland. After about 10 years, it became a distinguishable form of travelling, with its own methodology, style, and model, although it still remains a very unpopular and niche phenomenon. It presents a new and unrecognised issue also from the scientific point of view. Out of the research set that refers directly to the topics concerning the Polish backpacker tourism, one can point among others: Dłużewska (2004); Wiza (2013, 2014); Patyra, Dłużewska (2015); Jabłonkowska (2013, 2014). Clear, in-depth analyses are still lacking.

The purpose of the research presented in the paper was to identify and describe the multilayer structures of the backpacker tourist movement in Poland against the background of known foreign references, with emphasis laid on comparing two tourist groups: younger and elderly ones.

The described study is a continuation of research carried out in years 2011-2013 concerning the types of alternative tourism in Poland. The results will allow for gathering knowledge on the new (multiple) forms of travelling undertaken, among others, by Polish individual tourists. The article constitutes merely an introduction to the study issues.

\section{Material and methods}

The adopted research tool was a survey questionnaire. The authors used the basic paradigm of the questionnaire that had been employed by Jabłonkowska (2013) in the diagnosis of the Polish backpacker environment in previous years; the questionnaire was slightly modified for the needs of the present research. One type of questionnaire was constructed for both study groups. It was adjusted to the specificity of the performed analysis: edited in the Polish language, it included questions concerning the respondents' socio-demographic features (e.g. sex, age, profession, place of residence, financial status, education).

The study was conducted between October 2013 and June 2014. As it was not possible to perform comprehensive research (because, among others, of the lack of any quantitative research in 
the field of the Polish alternative tourism), the authors had to narrow the study to a sample chosen with the use of the purposive sampling method. It was acknowledged that a representative group would consist of people fulfilling two basic criteria at the same time: the identity one (they should admit their own participation in backpacking tourism) and the demographic one (allowing to locate the respondents in a group of either young people, within the age range of 18-25 years, or elderly people, aged 60-75). The respondents were recruited from websites and forums devoted to alternative tourism, as well as by means of social inquiry with the snowball sampling method.

The author realises that the presented survey research does not measure the whole population of the Polish backpackers. It seems extremely difficult to recruit a representative group of respondents with the use of randomization in the Polish research area, as the Polish backpackers still constitute a niche group to a significant degree, and they are extraordinarily scattered. There are no places allowing for a direst contact with them, which hinders collecting a random group in conditions that would make polling available.

Initially, 104 young people and 108 elderly people were recruited to the research. After the frame classification, which focused on the necessity to fulfil two criteria at the same time: the identity one and the demographic one, 200 people were included in the research (100 aged 18-25 years and 100 aged $60-75$ years $^{1}$ ). Equal number of respondents were left to the analysis in each research group, which assured compatibility. The polling was carried out in direct contact (35 young people and 32 elderly people), by telephone (18 young people and 50 elderly people), and via e-mail (47 young people and 18 elderly people).

The socio-demographic analysis comprised four modules, which especially characterise the type of travelling, according to foreign sources that present the contemporary state of backpacking research. These are: the demographic module (age, sex, place of residence); the relational module (marital and family status); the educational module (educational degree); the professional module (professional and financial status).

The result analysis was performed with the use of the statistical packet PQStat ver. 1.4.2.324. The relations between the distribution of questionnaire answers and the group of respondents were analysed with the chi ${ }^{2}$ test and the Fisher exact test. The probability at the level of $\mathrm{p}<0.05$ was assumed significant, and the probability at the level of $\mathrm{p}<0.01$ was assumed highly significant.

\section{Demographic conditions of the Polish backpackers}

\section{Age category analysis}

All the studies performed abroad so far emphasise features characteristic of backpacking (the classifying features). It is pointed out that this type of tourism is practiced especially by young people, most often at the age of 18-33 years (however, the age group of 22-27 years seems particularly

\footnotetext{
${ }^{1}$ Seniors, brought up in the traditions of tramping tourism, were also recruited. According to Cymańska-Garbowska and Steblik-Wlaźlak (2011), among others, both types of travelling present a methodological identity in the culture of the Polish tourism.
} 
active in the field). Backpacking is markedly popular among those who have already reached an education level but still have not gained an established position on the job market or, after several years of working experience, have not yet entered the following stage, described as 'life stabilization'. Sørensen (2003, p. 851-854) points out that backpacking is most often undertaken by people in the so-called transitional periods, brought about by the need to 'break away from the routine before it is too late'. However, a rapid statistical change in the age structure of backpackers can be observed in the recent years. The movement is being joined by the elderly in a more and more noticeable way. A report from 2006 informs about a rise in the activity of elderly backpackers by $4 \%$, especially those travelling in Southern Africa (ECI Africa, 2006); the Ministry of Tourism report from 2009 points at a 10\% higher participation of elderly backpackers in journeys in Australia and New Zealand (Backpacker sector New Zealand, 2010).

This unusual phenomenon reorganises the previous theories, extending the analysis realm by a new factor - an elderly person. In the 1990s, Pearce (1990) anticipated that backpacking would undergo constant changes. This is, according to Cohen (2011), a natural implication of the social changes in backpackers' self-perception. Backpacking is beginning to be perceived more as a way of life. Therefore, it is not characterised by the age of participants any more but - according to Sørensen (2003) - by their self-consciousness of travelling.

The analysis of the data collected by the author during the research performed among the Polish backpackers allows to show the validity of the thesis put forward by Sørensen (2003); what is more, it makes the thesis more precise, assuming the division into the two age groups. Figure 1 presents the age of the respondents, split into three sections, which reflect the transitional periods according to Sørensen. Young people (respondents) are ascribed the segment of early adulthood (after the maturity examination): 18-19 years of age; the segment of arising independence (graduates from bachelor degree studies and youth with learned profession): 21-22 years of age; and the segment of adulthood (graduates from master degree studies or people after the first years of working experience): 23-25 years of age. In the case of the elderly (respondents), the following segments were distinguished: the early retirement segment: 60-64 years of age; the segment of early old age: 65-69 years of age; and the pre-senile segment: 70-75 years of age (Steuden, 2011).

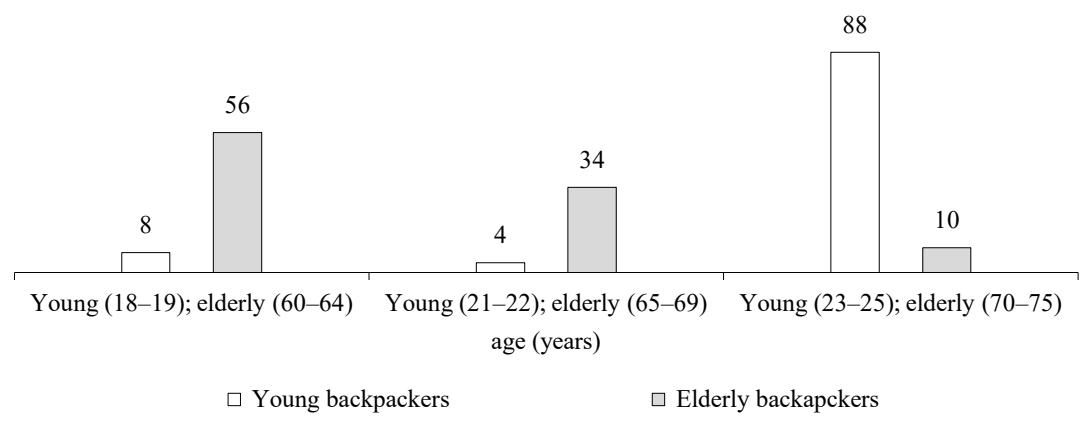

Figure 1. The structure of the examined sample of the Polish backpackers according to age (\%).

Source: own construction. 
A highly significant $\left(\mathrm{chi}^{2}=121.76, \mathrm{df}=2, \mathrm{p}<0.0001\right.$, Fisher exact test $\left.\mathrm{p}<0.0001\right)$ dependence of backpacker activity on the age group was observed. The backpacker activity in the particular age groups demonstrates inverse proportionality (Figure 1).

With the passage of years, the demand for backpacker tourism rises among young respondents and decreases among the elderly ones. The most numerous group of young backpackers are the 'young adults', aged 23-25 years (the third segment, 88\%); the most numerous group of elderly backpackers are the 'early retirement' segment, aged 60-64 years (the first segment, 56\%).

\section{Backpacker tourist activity with reference to sex}

In the international research literature, the category of sex in backpacker tourism has not been precisely defined. The results published so far are variable. Their diverse value does not allow to grasp the backpacker activity in the context of sex determination (e.g. Loker-Murphy, 1996; Murphy, 2001). However, Sørensen (2003) tries to point in his research at a noticeable difference emerging from studies performed among the backpacker environment in the developing countries. Here, Sørensen observes an increased activity in the male population (60/40).

Nevertheless, the research among the Polish backpackers does not provide evidence for straightforward opinion-forming declarations (Figure 2).

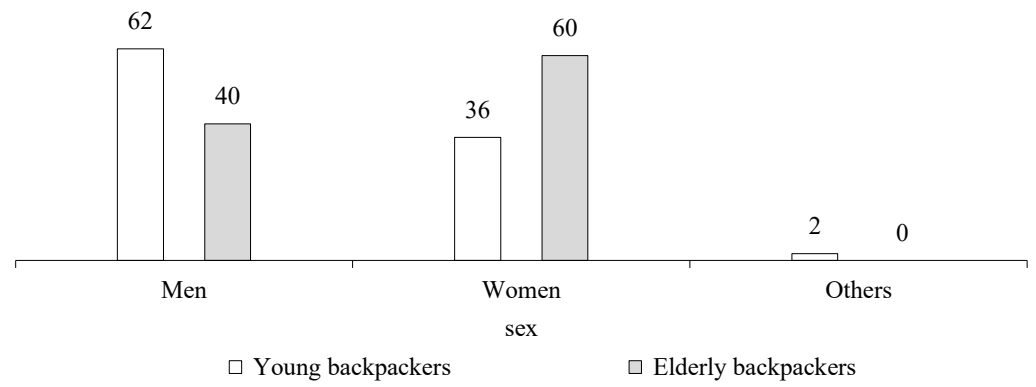

Figure 2. The structure of the examined sample of the Polish backpackers according to sex (\%)

Source: own construction.

A highly significant $\left(\mathrm{chi}^{2}=12.74, \mathrm{df}=2, \mathrm{p}=0.0017\right.$, Fisher exact test $\left.\mathrm{p}=0.0007\right)$ dependence of sex distribution on the research group was observed. The majority of young respondents are men, whereas the majority of elderly respondents are women.

The results presented in Figure 2 allow for a conclusion that there is a certain inverse proportionality within the age categories. Among the respondents of the young generation, the number of men prevails with reference to the general number of the analysed subjects by as much as $26 \%$. Among the elderly respondents, the number of women prevails by as much as $20 \%$. The proportions 
change with age: the older the respondents of the Polish (backpackers), the bigger participation of women in the type of alternative tourism under discussion.

\section{Agglomeration tendencies in the development of backpacking}

The international studies concerning backpacker tourism present the subject with reference to nationality, pointing at the remarkable activity of backpackers from North America, Australia, Asia, and Western Europe (especially from Great Britain, Ireland, Germany, or Scandinavian countries) (Sørensen, 2003; Pearce, Murphy, Brymer, 2009). The activity analyses related to specific countries do not provide information on the respondents' place of residence; however, backpackers' declarations mentioned in the papers include phrases indicating their city agglomeration origin (e.g. Wilson, Ateljevic, 2008).

In the group of the Polish backpackers taking part in the questionnaire, a highly significant dependence was observed between the place of residence and the study group, which could modify the opinions put forward in the world literature so far (Figure 3). The vast majority of respondents live in big cities. In the city classification, the division according to dimension classes was applied. Thus, big cities (over 100,000 inhabitants), medium cities (20,000-100,000 inhabitants), and small cities (under 20,000 inhabitants) were distinguished.

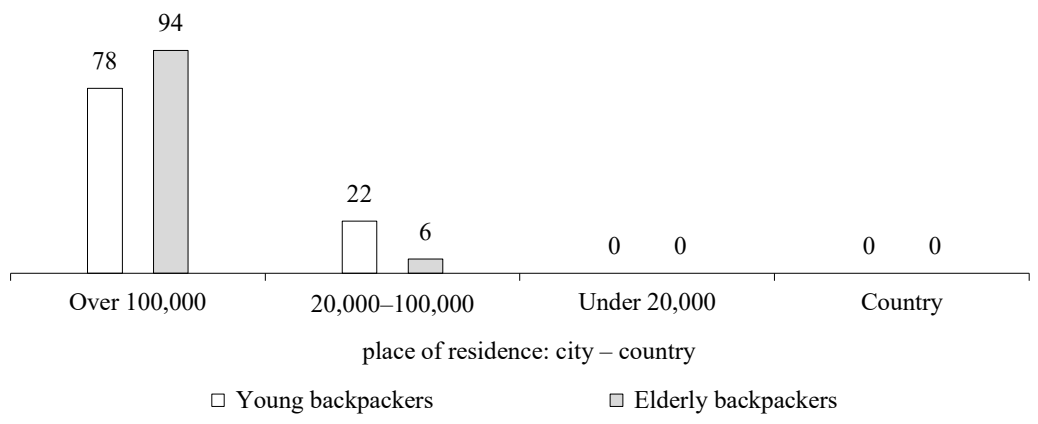

Figure 3. The structure of the examined sample of the Polish backpackers according to the place of residence (\%) Source: own construction.

A highly significant $\left(\mathrm{chi}^{2}=10.63, \mathrm{df}=1, \mathrm{p}=0.0011\right.$, Fisher exact test $\left.\mathrm{p}=0.0018\right)$ dependence of the place of residence distribution on the research group was observed. In both age groups, inhabitants of big cities prevail, although in the group of elderly respondents-backpackers the predominance turns out higher than in the group of young respondents-backpackers.

The basic place of residence of the questionnaire respondents were cities with a considerable socio-economic potential, referred to as big ones. As many as $94 \%$ of the elderly respondents included in the research and $78 \%$ of the young respondents come from these cities. None of the respondents pointed at a city of under 20,000 inhabitants or a country as their place of residence. 
Smaller centres in Poland are characterised by the so-called depopulation, resulting from unfavourable migration of the inhabitants, which is especially emphasised in demographic studies. The migration movement, oriented towards big urbanised centres, seems to be conditioned not only by the own economic and industrial development dynamics of the cities, but also by the scale of possibilities offered by cities to their inhabitants. The obtained result can therefore prove that backpacker tourism, both in the case of young respondents and elderly ones, is the type of tourism that meets the social and economic needs of people focused on their own development and self-realisation.

\section{The marital and family status of the Polish backpackers}

MacCannell (1992) notices that tourism develops, among others, on the basis of the emotional needs of people who, faced with the experience of social relations marked by artificiality and triviality in the local (or sometimes family) environment, look for real sensations, sincere relations, communities open to universal values and inter-cultural dialogue in remote geographic and cultural spaces. It therefore seems justified to suggest, as Riley (1988) already wrote, that backpacker travelling constitutes tourism of emotional crossroads. And it is not the question of a contemporary form of drifting. Backpackers, wherever they go and whatever their emotional reasons are to leave their family sites, always have the idea of coming back in mind (Sørensen, 2003).

Introducing the marital and family status analysis of tourists (both young and elderly) into the research on the Polish backpacking was supposed to indicate if there existed the motif, mentioned, among others, by Riley (1988), of the emotional crossroads or transitional periods associated with family experience in the Polish two backpacker generations (Sørensen, 2003).

The marital and family status of both young and elderly respondents was analysed (Figure 4).

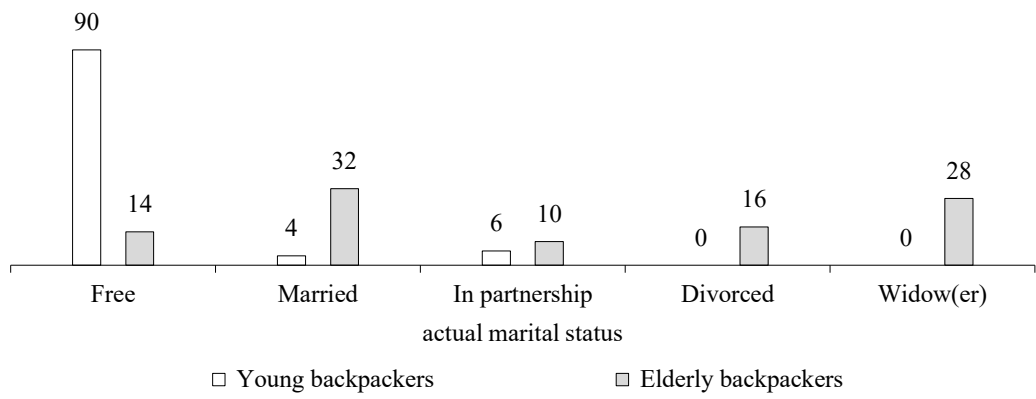

Figure 4. The structure of the examined sample of the Polish backpackers according to the actual marital status (\%) Source: own construction.

A highly significant $\left(\mathrm{chi}^{2}=122.32, \mathrm{df}=4, \mathrm{p}<0.0001\right.$, Fisher exact test $\left.\mathrm{p}<0.0001\right)$ dependence of marital status distribution on the research group was observed. The free status consists the 
dominating category in the group of young respondents; the most frequent answers in the group of elderly respondents refer to being married or being a widow/widower.

The vast majority of young respondents do not declare relational commitments legitimised by marriage. They are self-reliant, independent, unhampered. Among young respondens-backpackers, $90 \%$ of respondents point at the free status, only $4 \%$ are married, and $6 \%$ share their lives with a partner. In a question supplementing the basic questionnaire issues, young backpackers emphasised that they did not want to enter stable relations or family responsibilities $(80 \%)$, did not feel mature enough to take vital decisions (67\%), still had time for responsibilities (79\%), wanted to take advantage of the time space between the completion of the education process and the necessity to take a job (90\%), had to do something for themselves (66\%). All young people in the study declared the lack of children. Out of this age group, 49\% share their household with the parents, $10 \%$ share their household with the spouse or partner, and $41 \%$ earn a living on their own.

Respondents from the elderly generation represented a different point of view in this issue. Out of this group, 32\% subjects are married, $28 \%$ are widowed, $16 \%$ are divorced. Living in an informal partnership relation is declared by $10 \%$, and $14 \%$ represent free status.

Even if the analysis of marriage and family relation attitude of the young respondents allows one to agree with the foreign researchers' suggestions which refer to taking advantage of the socalled transitional periods by backpackers, the thesis dos not prove true in the group of elderly respondents in Poland. Here, relational factors dominate. The elderly specified their questionnaire answers by pointing out that their marital or family situation did not impact their choosing backpacker type journeys as they did not feel limited in this matter $(71 \%)$, they travelled with the consent and approval of the spouse/partner (40\%), they did not have family responsibilities which would hinder or restrain realising their travelling aspirations (70\%), the time of duties in their lives had already passed, and they could enjoy their lives now (88\%), they had arguments with the closest family and the journeys helped them compensate for the hardship of bearing negative emotions (7\%), they had too little time to wait for realising their travelling aspirations any longer (89\%).

Family responsibilities of elderly people (respondents) do not determine their free time or restrict their choices as for the way of spending it. Seniors-respondents travel, freely filling their retirement time, and realise their tourist needs that have not been satisfied before (first, for political reasons, then for family reasons, associated to a high degree with the Polish socio-cultural and economic conditions of the $20^{\text {th }}$ century) without the pressure of constant duties. Elderly backpackers' journeys, besides the issue of the limitations resulting from the transitional periods, seem to be a suspension 'in between'. The only pressure, not openly discussed, but remaining effective in the elderly people's self-consciousness, is the race against death. Among senior respondents, 12 people pointed very clearly that 'to be in time' was their important life responsibility.

\section{The capital of the Polish backpackers' academic education}

According to Richards and Wilson (2003), backpackers are educated people. Out of the respondents participating in the research, $70 \%$ declared belonging to an academic community, and 
some of them stated that they studied two faculties simultaneously. Sørensen (2003) claims that backpackers are often characterised by an outstanding level of education as compared with the mean level in their family countries. In the case of younger backpackers, in turn, who have not graduated from a university yet, continuing academic education can be observed after the journey. Niggel and Benson (2008), as well as many other researchers in the field, emphasised that there existed a dependence between backpackers' educational level and their preferred type of tourism. A kind of inter-relation between these factors can be noticed: education provides knowledge and skills necessary to plan, organise, and realise journeys; backpacking, on the other hand, opens the perspectives to understand and value various aspects of human life and human culture.

This specific parallel is also confirmed by the results of the analyses performed among the two groups of respondents (Figure 5).

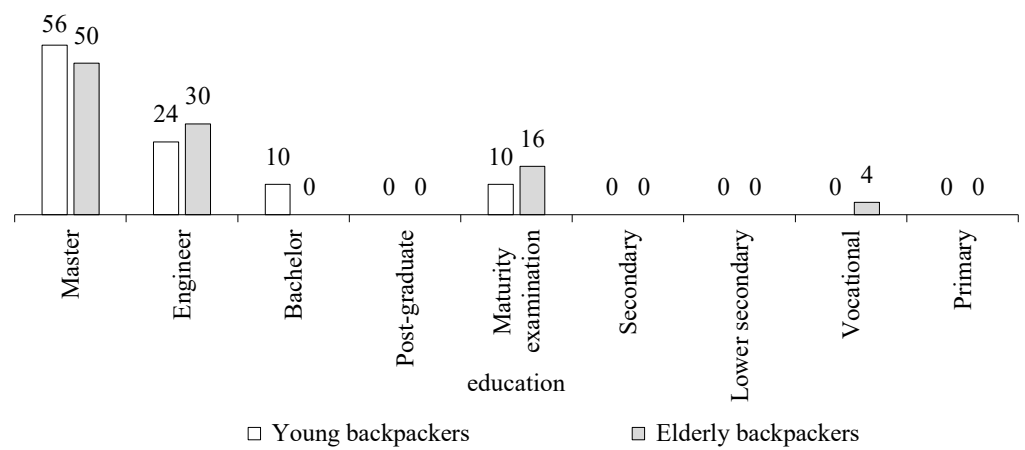

Figure 5. The structure of the examined sample of the Polish backpackers according to the education level (\%) Source: own construction.

A highly significant $\left(\mathrm{chi}^{2}=16.39, \mathrm{df}=4, \mathrm{p}=0.0025\right.$, Fisher exact test $\left.\mathrm{p}=0.0010\right)$ dependence of education level distribution on the research group was observed.

In both groups, the level of academic education turned out rather high. A master degree was declared by every second respondent in both the young group (56\%) and the elderly group (50\%). In the other segments the results were similar, too. An engineer degree was pointed at by $24 \%$ of the young people and $30 \%$ of the elderly. Every tenth respondent from among the researched backpackers gains their backpacker experience after the maturity examination. It can be observed that the lower age limit in active backpackers is decreasing all around the world. In the present research, however, no such phenomenon was perceived. In the community of the studied seniors, merely $16 \%$ completed their maturity level education. The only inconsiderable difference between the two groups can be recognised at the level one but last. Among the young respondents, there was no person with practical vocational education; in the elderly group, this kind of education was declared by $4 \%$ of the respondents. 
The results of the presented research point at some dependence between the choice of the type of alternative tourism (backpacking) being discussed and higher education in the group of respondents. The most significant justification for the inter-relation of education level and backpacking is the motivation that connects both elements, constituting an inspiration for undertaking tourist activity within. The desire to broaden one's general knowledge (in various areas, such as culture, geography, nature, politics, religion, history), to engage in social relations, to experience a wide range of adventures and self-realisation, to verify one's own capabilities - is basically conditioned by the level of education and the need for self-development, one of the factors of extending education.

\section{Economic and occupational conditions of the Polish backpackers}

\section{Professional qualifications}

In the foreign sources, no detailed analyses of backpackers' professional situation is provided. Foreign studies are limited to selected segments of demographic assessment, mainly because the target group was chosen from among students and people not old enough to have any professional experience yet.

The research performed among the Polish group of backpackers also demonstrates that people under the age of 25 years most often have not graduated from a university yet or are in the so-called transitional period at the moment (Figure 6).

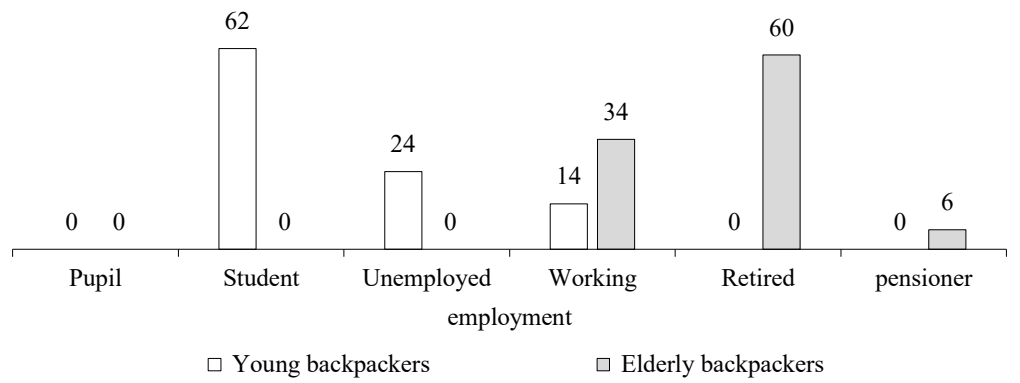

Figure $\boldsymbol{b}$. The structure of the examined sample of the Polish backpackers according to employment (\%)

Source: own construction.

A highly significant $\left(\mathrm{chi}^{2}=160.33, \mathrm{df}=4, \mathrm{p}<0.0001\right.$, Fisher exact test $\left.\mathrm{p}<0.0001\right)$ dependence of employment on the research group was observed.

The most numerous group among the young respondents were students (62\%), among seniors - the retired (60\%). Both students and retired people comprise more than a half of the respective age group. Their engagement in the type of tourism called backpacking is not associated with the necessity to adjust to a strictly defined time of employee leave. Temporary independence (both in 
the study period and during retirement) favours longer journeys, and travel calendar arrangement according to the needs, without any limitations.

The research did not indicate, however, if the respondents classifying themselves as students are students of a university and employees at the same time. In the complementary questionnaires, retired backpackers emphasised that they did not involve in additional professional responsibilities because they wanted to assign the last period of activity given to them, as well as the retirement benefits, worked out through the lifetime, for travelling (75\%), for personal development (59\%), for exploration and discovering (87\%), for being active (81\%), for themselves (41\%). Young respondents revealed astonishingly similar perception of the advantage of responsibility-free time value with reference to backpacker travelling. They are, too, on the threshold of activity, yet on the opposite pole - the initial one. They want to assign the last period of professional and social independence for travelling (91\%), for getting to know other cultures (87\%), for adventure (94\%), for verification of their own capabilities (61\%), for fun (45\%).

Among the senior respondents, there was a group (slightly over 1/3, 34\%) of people still active in the professional field $(60 \%$ in the private sector, $11 \%$ in the sector of trade and services, $29 \%$ in the sector of education). Out of the elderly respondents, $6 \%$ were pensioners.

The professionally active young representatives of the researched backpacker community (14\%) declared various places of employment (most often temporary): $71 \%$ in the trade and services sector, $29 \%$ in the tourism and recreation sector.

No unemployed person was found among the senior respondents; among the young ones, only $24 \%$ were unemployed.

\section{The financial situation}

One of the basic features the are indicated to define backpacking is the low cost, associated in the foreign literature of the subject with the economic situation of this tourism type participants. It is emphasised that backpackers' limited financial resources favour decisions to choose this alternative tourism type, providing the possibility of inexpensive travelling. Therefore, backpackers prefer inexpensive accommodation, inexpensive means of transport, inexpensive food etc. This is why O'Reilly (2006, p. 1005-1006) maintains that the specificity of individual travelling would be much better reflected by the term 'budget travelling', not 'backpacking'.

In the Polish reality, inexpensive travelling does not basically result from economic motives, which is proved by the results of the respondents' financial situation study in the two research groups. The results are illustrated in Figure 7. In order to achieve a reasonably objective outcome, the authors employed the indices of a monthly income per one person in the family (net income). The backpackers' individual income was not taken into consideration, as these data would not reflect the actual situation: many people aged 18-25 years make a living with the help of scholarships, parents' support, and other sources of financial means (e.g. seasonal work, odd jobs). 


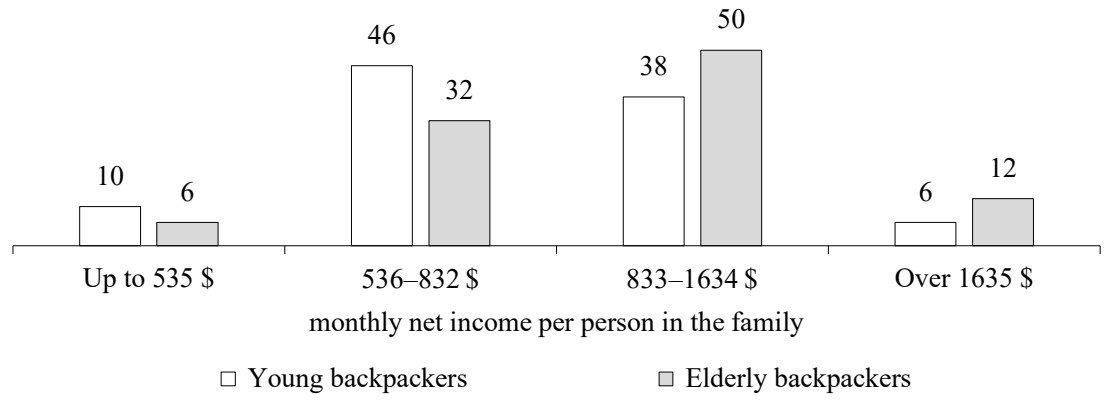

Figure 7. The structure of the examined sample of the Polish backpackers according to the financial status ${ }^{2}(\%)$ Source: own construction.

No significant $\left(\mathrm{chi}^{2}=7.15, \mathrm{df}=3, \mathrm{p}=0.0673\right.$, Fisher exact test $\mathrm{p}=0.0694$ ) dependence was observed between the assignment to a group according to the income level and belonging to a research group according to age.

Many surveyed backpackers were classified in the monthly financial range between 833 and 1634 USD per person (38\% of the young respondents, $50 \%$ of the elderly ones). This result implies that a vast majority of backpackers, declaring participation in low-cost tourism, do not belong to the worst-paid group. As few as every tenth person out of the young respondents and even fewer from among seniors had their place in this segment of people living within the limits of the so-called national minimum wage ${ }^{3}$. When counted together with the percentage of respondents whose monthly income does not exceed 832 USD per person, the total contribution of young backpackers with this income level turns out higher as compared with backpackers declaring medium or higher income level (56\% vs. $44 \%$ ); in the elderly group, the proportion is opposite (38\% vs. $62 \%$ ). Although the group with the highest income is relatively not very numerous $(6 \%$ of the young respondents and $12 \%$ of seniors), it should be noted that they constitute almost $1 / 5$ of all the surveyed backpackers.

\section{Conclusions}

Broadening of the research on backpacking being carried out throughout the world, in a wide context and at an exceptionally high level, with a new study area - Poland - enables complementing the knowledge on backpacking. The performed survey allowed to describe the backpacker tourist movement in Poland, with a special emphasis on comparing two groups of backpacker respondents: young and elderly ones. The presented paper, comprising the survey among the elderly backpacker sector, seems to be ahead of foreign research.

${ }^{2}$ Counted according to the exchange rates of Narodowy Bank Polski (National Polish Bank) of November 19, 2014, 21:45 (1\$=3.3655 PLN).

${ }^{3}$ Since January 1, 2014 the minimum net wage in Poland equals $369 \$(80 \%$, i.e. $295 \$$ in the first year of work). 
In the socio-demographic context, the results allowed to outline several factors, which, although appear to differentiate the two surveyed age groups, remain common for them in a sense at least in the studied plane. When analysing the age groups of both young and elderly respondents (participants of backpacker tourism), one can observe that neither the very early stage of entering adulthood nor the very late phase, associated with crossing the threshold of senility, is specific for backpacker activity. Among the surveyed subjects, most people travel at the age of 23-25 years (the age of opening active maturity) or 60-64 years (the age of its coming to an end).

It is not possible to establish a special participation of one sex in backpacking, as both men and women travel. One can, however, notice a juxtaposition tendency in the configuration of both surveyed communities. The younger the research group, the less the participation of women; the older the group, the bigger their travelling activity.

Backpacker journeys (regardless of the age group) are mainly the domain of respondents living in cities of over 100,000 inhabitants. City agglomerations seem to develop travelling motivations, as well as provide the essential tourist background (free access to transport, intellectual, and social infrastructure).

Statistically, with reference to both surveyed groups (young and elderly), backpacking is a type of tourism of educated people, without family or professional responsibilities, and - if of those connected with business, the setting is mainly services or the private sector.

The last of the presented issues referred to the backpackers' financial situation. The vast majority of foreign studies emphasise the low-cost trait of backpacking. In the Polish reality, this feature should not be perceived in the light of the respondents' poverty, but through the reference to their choices. As it seems, it is not any shortage that induces the choice of budget travelling, but the willingness to change the economic status for a holiday.

\section{Referencess}

Aitchison, C. (2003). Gender and Leisure: Social and Cultural Perspectives. Routledge: London.

Backpacker sector New Zealand (2010). Series a3. Available at: www.tourismresearch.govt.nz/accprofile (20.05.2012).

Cohen, E. (2003). Backpacking: Diversity and change. Tourism and Cultural Change, 1 (2): 95-110.

Cohen, S.A. (2011). Lifestyle Travellers. Backpacking as a Way of Life. Annals of Tourism Research, 38 (4): $1535-1555$.

Cymańska-Garbowska, B., Steblik-Wlaźlak, B. (2011). Podstawy turystyki. Warszawa: Wydawnictwo REA.

Dłużewska, A. (2004). Bag Packers czyli ludzie z plecakiem. Biznes i Turystyka, 25: 26-32.

ECI Africa (2006). Backpacking Tourism Sector Study. Johannesburg.

Fischer, J., Rostami, S., Peet, A., Dean, J., Debattista, J., Allen, K. (2010). Sex, drugs and backpacking: Study report. Queensland: Alcohol Education \& Rehabilitation Foundation Ltd.

Gaj, J. (2006). Dzieje turystyki w Polsce. Warszawa: DrukTur.

Jabłonkowska, J.B. (2013). Backpacker tourism among Polish seniors. In: K. Denek, A. Kamińska, P. Oleśniewicz (eds), Education and upbringing in the educational school system (pp. 319-329). Sosnowiec: Oficyna Wydawnicza 'Humanitas'.

Jabłonkowska, J.B. (2014). Backpacking a dwa pokolenia turystów - wstęp do badań nad definicją. Rozprawy Naukowe AWF we Wroctawiu 46, 37-45.

Jarvis, J., Peel, V. (2005). The Backpacker Boom Around the Globe. Centre for Global Movements. Melbourne: Monash University. 
Loker-Murphy, L. (1996). Backpackers in Australia: A Motivation-based Segmentation Study. Journal of Travel and Tourism Marketing, 5 (4), 23-45.

MacCannell, D. (1992). Empty Meeting Grounds: The Tourist Papers. London: Routledge.

Murphy, L. (2001). Exploring Social Interactions of Backpackers. Annals of Tourism Research, 28 (1), $50-67$.

Niggel, Ch., Benson, A. (2008). Exploring the Motivations of Backpackers: The Case of South Africa. In: K. Hannam, I. Ateljevic (eds), Backpacker Tourism: Concepts and Profiles (pp. 144-156). Clevedon-Buffalo-Toronto: Channel View Publications.

O’Reilly, C.C. (2006). From Drifter to Gap Year Tourist: Mainstreaming Backpacker Travel. Annals of Tourism Research, 33 (4), 998-1017.

Patyra, A., Dłużewska, A. (2015). Backpacking - historia, ramy, rozwój. Turystyka kulturowa, 11, 40-54.

Pearce, P.L. (1990). The backpacker phenomenon: Preliminary answers to basic questions. Townsville: James Cook University.

Pearce, P.L. (2006). Backpackers and backpacking - a fresh look. Tourism Recreation Research, 31 (3), 53-59.

Pearce, P.L., Murphy, L., Brymer, E. (2009). Evolution of the backpacker market and the potential for Australian tourism. Queensland: Gold Coast.

Richards, G., Wilson, J. (2003). Today's Youth Travellers: Tomorrow's Global Nomads. New Horizons in Youth and Student Travel. A Report for the International Student Travel Confederation (ISTC) and Association of Tourism and Leisure Education (ATLAS). Amsterdam: International Student Travel Confederation (ISTC).

Riley, P. (1988). Road Culture of International Long-Term Budget Travelers. Annals of Tourism Research, 15 (3), 313 -328.

Sørensen, A. (2003). Backpacker ethnography. Annals of Tourism Research, 30 (4), 847-867.

Steuden, S. (2011). Psychologia starzenia się i starości. Warszawa: PWN.

Wilson, E., Ateljevic, I. (2008). Challenging the 'Tourist Other' Dualism: Gender, Backpackers and the Embodiment of Tourism Research. In: K. Hannam, I. Ateljevic (eds). Backpacker Tourism: Concepts and Profiles (pp. 95-110). Clevedon-Buffalo-Toronto: Channel View Publications.

Wiza, A. (2013). Uczenie się z podróży w narracjach turystów indywidualnych (backpackersów). Poznań: AWF.

Wiza, A. (2014), Backpacking w perspektywie odległych miejsc i kultur poznawanego świata oraz siebie. Turystyka Kulturowa, 11, 39-52.

Tamazos, K. (2015). Backpacking Through an Ontology of Becoming: A Never-ending Cycle of Journeys: The Backpacker as a Campbellian Hero. International Journal of Tourism Research, 4, 1-19. 
DWA POKOLENIA BACKPACKERÓW.

IDENTYFIKACJA WIELOPRZEKROJOWYCH STRUKTUR UCZESTNIKÓW

TURYSTYKI BACKPACKERSKIEJ W POLSCE

SŁOWA KLUCZOWE

STRESZCZENIE turystyka alternatywna, backpacking, seniorzy, podróże, Polska

Backpacking w Polsce jest zagadnieniem wciąż nowym i nierozpoznanym. Aby znaleźć odpowiedź na pytania o profil demograficzny polskich backpackerów, przeprowadzono od października 2013 do czerwca 2014 roku badania. Do wybrania grupy reprezentatywnej posłużono się metodą celową. Za podstawowe kryterium selekcji przyjęto kryterium tożsamościowe oraz demograficzne. Wybrano 100 osób z przedziału wiekowego pomiędzy 18. a 25. rokiem życia oraz 100 osób - pomiędzy 60. a 75. rokiem życia. Celem badania była identyfikacja i opis wieloprzekrojowych struktur uczestników backpackingu w Polsce. W artykule zostały zaprezentowane wyniki ukazujące społeczno-demograficzne aspekty polskiego backpackingu młodego i senioralnego pokolenia. 